\title{
Regulation of glucose transporter (GLUT 3) and aldose reductase mRNA in bovine retinal endothelial cells and retinal pericytes in high glucose and high galactose culture
}

\author{
R. M.Knott, M. Robertson, J. V.Forrester \\ Department of Ophthalmology, University of Aberdeen, Scotland, UK
}

\begin{abstract}
Summary. The regulation of GLUT-3 and aldose reductase mRNA in retinal endothelial cells and retinal pericytes was studied in response to variations in the extracellular concentration of hexoses. In physiological concentrations of glucose $(5 \mathrm{mmol} / 1)$, an increase in the level of GLUT-3 mRNA was observed in cultured cells compared to the level of mRNA found in the absence of glucose. In contrast, there was little change in the level of GLUT-3 mRNA when the cells were cultured in the presence of $5 \mathrm{mmol} / \mathrm{l}$ galactose. In high concentrations of glucose, there was a decline in GLUT-3 mRNA indicating that the GLUT-3 mRNA is regulated by the extracellular concentration of glucose. In contrast, at both $5 \mathrm{mmol} / \mathrm{l}$ and $25 \mathrm{mmol} / 1$ glucose, the level of aldose reductase mRNA was increased. Furthermore, there were dif-
\end{abstract}

ferences in the magnitude of the increase of aldose reductase mRNA between bovine retinal pericytes and bovine retinal endothelial cells with a greater increase being observed in the pericytes. We propose that this demonstration of a facilitative glucose transporter system within retinal cells, and in particular the specific response to different hexoses and the known distinct kinetic parameters of the transporter system in specific cell types, highlights the heterogeneity of hexose transport mechanisms in retinal cells. Thus, hypergalactosaemia as a model system for the study of diabetic retinopathy should be used with caution.

Key words: Glucose transport, diabetic retinopathy, GLUT 3 , aldose reductase.
Diabetic retinopathy is one of the most common and serious of the vascular complications of diabetes leading to visual loss $[1,2]$. The basis for diabetic-related complications is believed to be the presence of chronic hyperglycaemia, although the precise mechanism of tissue damage is unclear. There are clearly differing effects of hyperglycaemia on the various tissues and cells that are exposed to high circulating glucose concentrations, with a consequent range of physiological and pathological responses.

The transport of glucose across the cell membrane is facilitated by a family of glucose transporter proteins [3]. Different cells have one or more of several distinct types of transport systems with properties that are compatible with their tissue of origin. Of interest in this study, is the expression of the brain-type glucose transporter (GLUT 3). GLUT 3 has previously been found in the brain associated with neuronal cells $[4,5]$ and microvessels [6]. GLUT-3 mRNA has now also been identified in both retinal endothelial cells and retinal pericytes (unpublished observations). Since diabetic complications are predominantly microvascular in origin, it is possible that abnormalities in glucose transport and specifically GLUT3, may occur in retinal vascular cells as a result of diabetes mellitus.
We have examined the expression of GLUT-3 mRNA in retinal endothelial cells and retinal pericytes in conjunction with the expression of aldose reductase mRNA. Aldose reductase has been implicated in the pathogenesis of several diabetic complications, including diabetic retinopathy $[7,8]$. However, associations between aldose reductase and diabetes-like ocular complications are less marked in experimental models of diabetes, than in experimentally-induced hypergalactosaemia [9-11]. We therefore determined the relative changes in the level of GLUT-3 and aldose reductase mRNA in response to high concentrations of glucose and galactose.

\section{Materials and methods}

\section{Cell culture}

Bovine retinal endothelial cells (BREC): Bovine eyes were obtained from a local abattoir and were used on the day of enucleation. The retina was removed from each eye and homogenized in Glasgow's minimal essential medium (Gibco, Paisley, Scotland, UK). The tissue was then treated for $3 \mathrm{~h}$ with collagenase at $37^{\circ} \mathrm{C}$ and the resulting cells were pelleted by centrifugation. A pool of cells from four retinae were used to seed one fibronectin-coated $75-\mathrm{cm}^{2}$ flask. 
The following day the cells were washed in Hanks' balanced salt solution and replaced with the appropriate test medium. The cells were harvested for RNA extraction when the cultures were approximately $80 \%$ confluent which occurred 3-5 days after the initial seeding of the flask. The endothelial cells were incubated in medium containing glucose or galactose for approximately 3 days prior to harvesting.

$B o v i n e$ retinal pericytes ( $B R P$ ): Retinal cells from bovine eyes were obtained as previously outlined. However, cells from eight retinae were required to seed one uncoated $75-\mathrm{cm}^{2}$ flask. The flasks were lightly trypsinized on two subsequent occasions over the following 14 days to remove any contaminating endothelial cells. The flasks were confluent approximately 21-28 days later. The cells were incubated in the respective media for approximately 3 days prior to harvesting.

Media: Glucose free media (Gibco) was used for all of the experimental conditions. The media was supplemented with $5 \%$ plasma derived serum for the culture of $B R E C, 10 \%$ fetal calf serum for the culture of BRP and various concentrations of D-glucose and Dgalactose as specified. Cell viability was maintained throughout the period of culture in the appropriate media.

\section{RNA extraction and electrophoresis}

The media was drained from the cell monolayers and the cells were washed three times in phosphate-buffered saline $(0.14 \mathrm{~mol} / \mathrm{l}$ sodium chloride, $2.7 \mathrm{mmol} / \mathrm{l}$ potassium chloride, $8.1 \mathrm{mmol} / \mathrm{l}$ disodium hydrogen phosphate, $1.4 \mathrm{mmol} / \mathrm{l}$ potassium dihydrogen phosphate). The RNA was extracted using an adapation of the Chomczynski and Sacchi [12] method. Briefly, to each $75-\mathrm{cm}^{2}$ flask, $5 \mathrm{ml}$ of a denaturing solution was added, containing $4 \mathrm{~mol} / /$ guanidinium isothiocyanate, $25 \mathrm{mmol} / \mathrm{l}$ sodium citrate $(\mathrm{pH} 7.0), 0.5 \%$ sarkosyl and $0.1 \mathrm{~mol} / 12-$ mercaptoethanol. The RNA was extracted using phenol-chloroformiosoamyl alcohol and the aqueous layer was removed. The RNA was precipitated with an equal volume of isopropanol and further concentrated with a second isopropanol precipitation. The resulting RNA pellet was then washed with $75 \%$ ethanol and finally resuspended in diethylpyrocarbonate-treated distilled water. The concentration of the RNA was determined spectrophotometrically at $260 \mathrm{~nm}$.

The RNA was resolved by electrophoresis in a $1.2 \%$ agarose gel containing formaldehyde. Each sample was analysed in duplicate using $10-20 \mu \mathrm{g}$ of RNA per lane. The gel was run at $60 \mathrm{~V}$ for $4 \mathrm{~h}$ and the RNA was subsequently visualized by staining with ethidium bromide. The RNA was transferred to a nylon membrane (HybondN; Amersham International, Amersham, Bucks., UK) by overnight capillary blotting and immobilized by exposure to short-wave ultraviolet light (Spectrolinker; Scotlab, Coatbridge, Scotland UK).

RNA was also transferred to membranes using a standard dot blot procedure. An aliquot of $10 \mu \mathrm{g}$ of the appropriate RNA sample was applied to a nylon membrane using a dot blot manifold (Gibco) with vacuum pressure. The RNA was then immobilized using ultraviolet light, as previously outlined.

The cDNA probes used for this study were as follows: the GLUT3 probe was a 911 base pair EcoR1 fragment [13], the aldose reductase cDNA was a 1.2 kilobase (kb) ECoR1 fragment [14] and the $\alpha$ actin probe was a $1.7 \mathrm{~kb}$ Pst 1 fragment of a genomic clone subcloned into PBR322.

The membranes were hybridized at $42^{\circ} \mathrm{C}$ for $6 \mathrm{~h}$ in buffer consisting of $50 \%$ formamide, $10 \%$ dextran sulphate, $0.2 \%$ polyvinylpyrrolidone, $0.2 \%$ bovine serum albumin, $2 \%$ Ficoll, $0.05 \mathrm{~mol} / \mathrm{l}$ Tris- $\mathrm{HCl}$, (pH 7.5), $1.0 \mathrm{~mol} / \mathrm{N} \mathrm{NaCl}, 0.1 \%$ sodium pyrophosphate, $1.0 \%$ SDS and denatured salmon sperm DNA ( $>100 \mu \mathrm{g} / \mathrm{ml})$. The appropriate probe was labelled by random priming with $\alpha$-dCTP using the Megaprime DNA labelling System (Amersham) and separated from the unincorporated labelled nucleotides using a Sephadex G-50 column. The specific activity of the various cDNAs was routinely $10^{6} \mathrm{cpm} / \mathrm{ng}$ DNA. The labelled probe was made up in the hybridisation buffer (excluding dextran sulphate) and added to the existing hybridisation mixture. The membranes were hybridised at $42^{\circ} \mathrm{C}$ for $16 \mathrm{~h}$, after which time the non-specific radioactivity was removed by the following washing procedures; $2 \times \mathrm{SSC}(0.3 \mathrm{~mol} / 1$ $\mathrm{NaCl} / 30 \mathrm{mmol} / \mathrm{l}$ sodium citrate, $\mathrm{pH} 7.0$ ) at room temperature for $5 \mathrm{~min} ; 0.5 \times \mathrm{SSC} / 1 \% \mathrm{SDS}$ at $50^{\circ} \mathrm{C}$ for $30 \mathrm{~min}$ (or at $65^{\circ} \mathrm{C}$ for the aldose reductase cDNA); $0.2 \times \mathrm{SSC}$ at room temperature for $30 \mathrm{~min}$. Each procedure was carried out in duplicate and the filters were either quantified or laid down in autoradiography cassettes containing intensifying screens, with hyperfilm $\mathrm{MP}$, at $-70^{\circ} \mathrm{C}$. The length of exposure varied from 7 to 10 days.

\section{Quantitation}

Each of the dot blot membranes of the test RNA were hybridised with the GLUT-3 probe, followed by aldose reductase and finally $\alpha$ actin. After each hybridisation had been carried out the level of radioactivity on the filters was determined using the Matrix ${ }_{96}$ (Canberra, Packard, Pangbourne, Berks., UK) [15]. The $\alpha$-actin/GLUT-3 and the $\alpha$-actin/aldose reductase ratio for each sample was determined. The level of the respective mRNAs in glucose-free medium is represented as $100 \%$ and the effect of the addition of glucose or galactose to the medium is given in relation to this value.

\section{Statistical analysis}

Statistical analysis of the data was carried out using a modification of the Student's $t$-test which takes into consideration the comparison of a constant value of $100 \%$ for the respective control populations.

\section{Results}

Detection of GLUT-3 and aldose reductase $M R N A$ in retinal cells. A single specific band of $4.1 \mathrm{~kb}$ was detected by Northern hybridisation of total RNA extracted from BRP after hybridisation with the GLUT-3 cDNA probe (Fig. 1). This is consistent with previous observations of GLUT-3 mRNA in brain tissue [16]. Aldose reductase mRNA was also detected in BRP (Fig. 1). A single band corresponding to $1.6 \mathrm{~kb}$ was evident which is consistent with previous reports [17]. Similar results were obtained with BREC for both the GLUT-3 and the aldose reductase mRNA (data not shown).

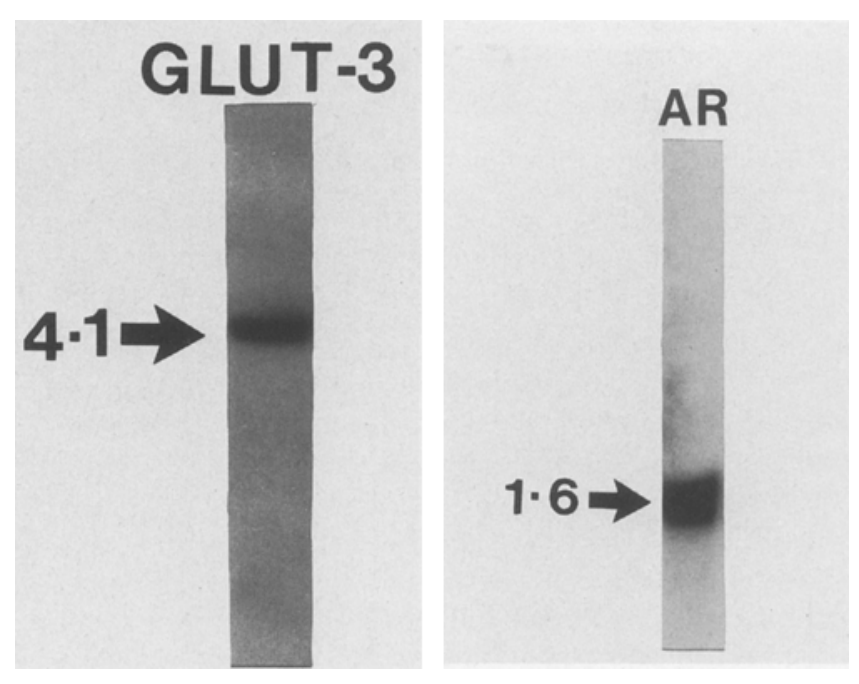

Fig. 1. Northern hybridisation of total RNA $(20 \mu \mathrm{g})$ extracted from bovine retinal pericytes showing GLUT-3 (left) and aldose reductase mRNA (right) 


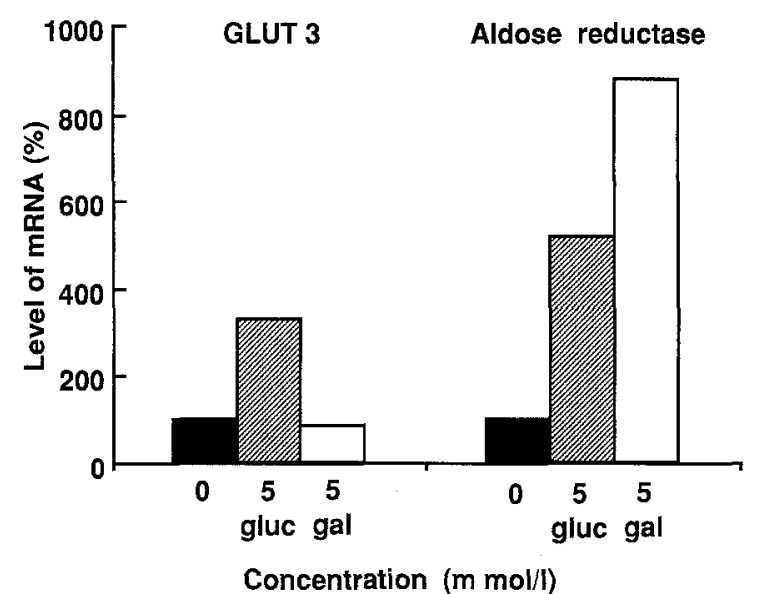

Fig. 2. Quantitative analysis of the level of GLUT-3 and aldose reductase mRNA in bovine pericytes incubated in media containing $0 \mathrm{mmol} / \mathrm{l}$ glucose, glucose (gluc) $5 \mathrm{mmol} / 1$ and galactose (gal) $5 \mathrm{mmol} / \mathrm{l}$. The changes in the level of these mRNAs are given as a ratio of $\alpha$-actin mRNA levels in the appropriate conditions. The level of expression of the respective mRNAs in cells incubated in glucose-free medium is given as $100 \%$ and the effect of the addition of galactose or glucose to the medium is given relative to this level. GLUT-3 mRNA increased significantly $(p<0.01)$ in response to $5 \mathrm{mmol} / \mathrm{l}$ glucose while no change was evident in response to $5 \mathrm{mmol} / 1$ galactose

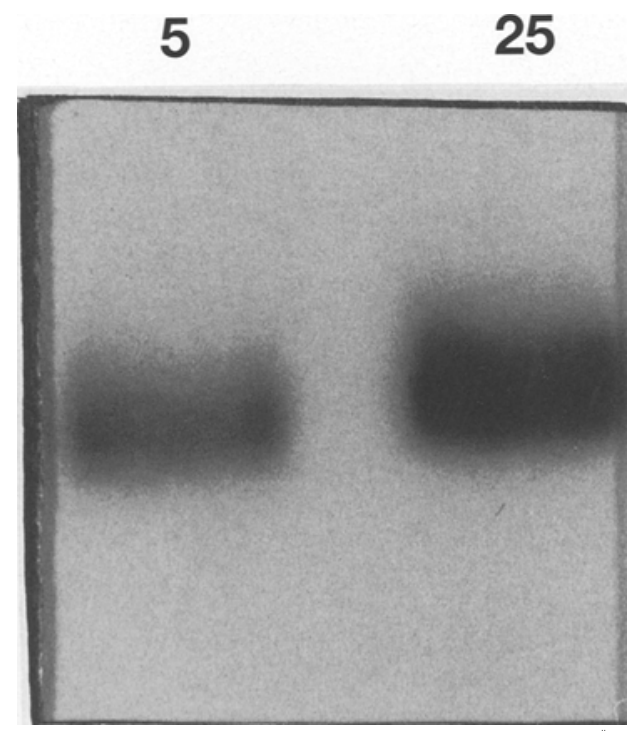

Fig.3. Northern hybridisation showing the relative changes of aldose reductase mRNA in bovine retinal pericytes exposed to $5 \mathrm{mmol} / \mathrm{l}$ and $25 \mathrm{mmol} / \mathrm{l}$ galactose

Regulation of aldose reductase and GLUT-3 $m$ RNA in retinal pericytes and retinal endothelial cells cultured in galactose and glucose. Northern hybridisation of total RNA extracted from bovine retinal pericytes incubated in $5 \mathrm{mmol} / \mathrm{l}$ glucose or $5 \mathrm{mmol} / \mathrm{l}$ galactose indicated differential regulation of GLUT-3 mRNA. The level of mRNA in these cells was quantified using the Matrix ${ }_{96}$ and the mean values of three samples are shown in Figure 2. This is representative of three experiments. There was only a slight increase $(127 \%)$ in the level of GLUT-3 mRNA in cells incubated in galactose while more than a three-fold increase $(328 \%$, $p<0.001$ ) was evident in those cells incubated in glucose-

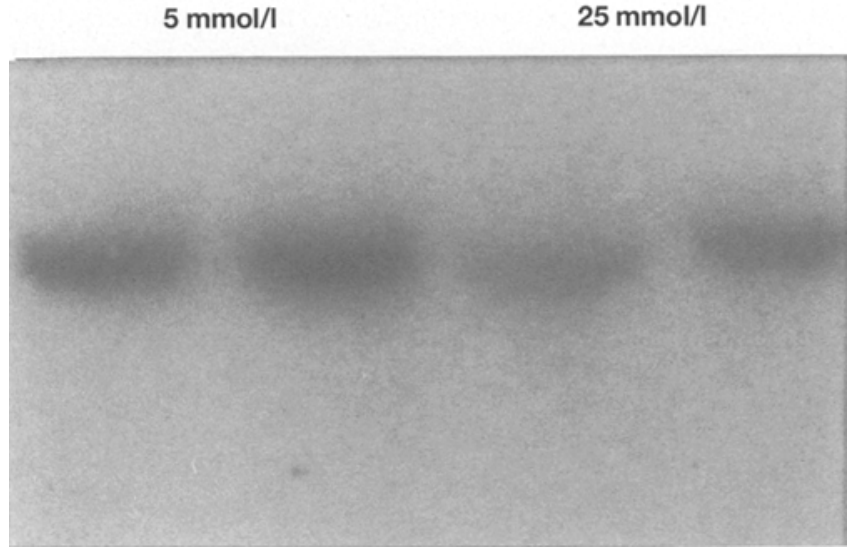

Fig.4. Northern hybridisation of total RNA hybridised with the GLUT-3 cDNA probe. The results shown are for cells incubated in $5 \mathrm{mmol} / \mathrm{l}$ and $25 \mathrm{mmol} / \mathrm{l}$ glucose

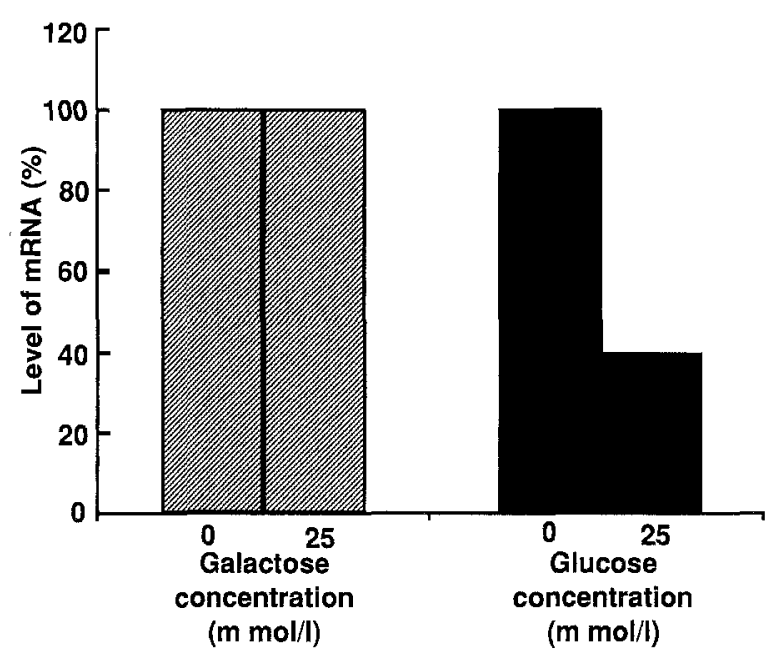

Fig.5. Quantitative analysis of the level of GLUT-3 mRNA in cells incubated in $0 \mathrm{mmol} / 1$ glucose or galactose and $25 \mathrm{mmol} / \mathrm{lg}$ glucose or galactose

supplemented medium. In contrast, increases were also evident in the level of aldose reductase mRNA in response to the presence of either glucose and galactose in the medium (glucose $517 \%, p<0.05$; galactose $578 \%, p<0.05$ ).

The changes observed in the level of the respective mRNAs in hyperglycaemic and hypergalactosaemic conditions is also shown qualitatively with Northern hybridisations for aldose reductase (Fig. 3) and GLUT 3 (Fig. 4).

Differential regulation of GLUT-3 and aldose reductase MRNA in BREC and BRP cultured in high concentrations of glucose and galactose. We studied further the regulation of GLUT-3 and aldose reductase mRNA in high glucose concentrations. Exposure of BREC and BRP to $5 \mathrm{mmol} / \mathrm{l}$ glucose caused significant increases in GLUT-3 and aldose reductase mRNA (Fig. 2). However, when the cells were cultured in $25 \mathrm{mmol} / \mathrm{lg}$ glucose (Fig. 5) there was a reduction in detectable GLUT- 3 mRNA (to $39 \%$ and $85 \%$ of control cultures for BREC and BRP, respectively) indicating that both cell types possessed homeostatic mechanisms for reducing glucose uptake in the presence of excessive extrac- 
ellular glucose. The same cells however, responded differently with regard to aldose reductase mRNA; whereas in $25 \mathrm{mmol} / \mathrm{l}$ glucose BREC expressed increased levels of aldose reductase mRNA ( $167 \%$ ), in $25 \mathrm{mmol} / \mathrm{lglucose}, \mathrm{BRP}$ expressed significantly higher levels of aldose reductase mRNA $(878 \%)$. The decrease in the level of GLUT-3 mRNA in BREC which had been cultured in $25 \mathrm{mmol} / \mathrm{l}$ glucose was not evident when the cells were incubated in $25 \mathrm{mmol} / 1$ galactose (Fig. 5), further highlighting that different regulatory mechanisms for the two hexoses exist.

Regulation of GLUT-3 and aldose reductase $M R N A$ in $B R E C$ and BRP cultured in high concentrations of glucose. BRP cultured in increasing glucose concentrations expressed corresponding increases in the level of aldose reductase mRNA, to $517 \%$ in $5 \mathrm{mmol} / \mathrm{l}$ glucose $(p<0.05)$ and $878 \%(p<0.05)$ in $25 \mathrm{mmol} / \mathrm{l}$ glucose (Fig. 6). However, the same cells showed an initial increase in the level of GLUT-3 mRNA ( $328 \% ; p<0.01)$ in $5 \mathrm{mmol} / 1$ glucose,

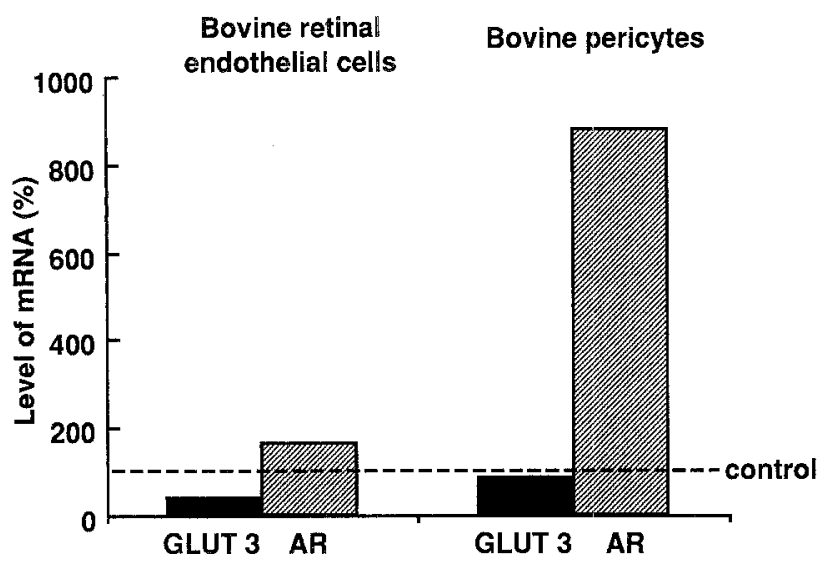

Fig. 6. Quantitative analysis of the level of GLUT-3 and aldose reductase (AR) mRNA in bovine retinal endothelial cells and bovine retinal pericytes incubated in media containing $25 \mathrm{mmol} / \mathrm{l}$ glucose. The level of mRNA in control cultures in the absence of glucose are indicated by dashed lines $(100 \%)$

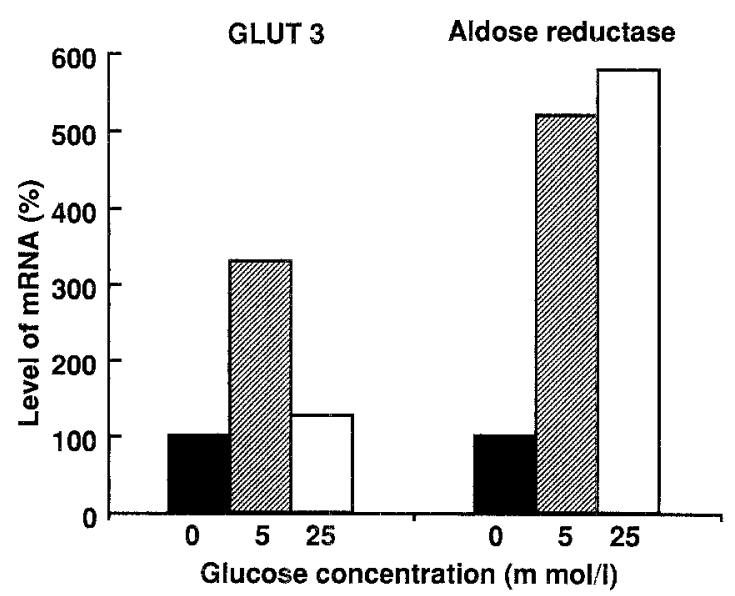

Fig. 7. Quantitative analysis of the level of GLUT-3 and aldose reductase $\mathrm{mRNAs}$ in bovine retinal pericytes exposed to $0 \mathrm{mmol} / \mathrm{l}$, $5 \mathrm{mmol} / \mathrm{l}$ and $25 \mathrm{mmol} / \mathrm{lg}$ glucose. A significant increase in the level of aldose reductase mRNA was observed with increasing glucose concentrations, while a significant decline was observed in the level of GLUT-3 mRNA in response to the increase in the level of glucose while in $25 \mathrm{mmol} / \mathrm{lglucose}$ there was a significant decline of GLUT-3 mRNA $(p<0.05)$ (Fig. 7). These results indicate that there was specific differential regulation of the aldose reductase and GLUT-3 mRNA.

\section{Discussion}

Retinal cells are regarded as insulin insensitive [18] and therefore less able to regulate their glucose intake in hyperglycaemic conditions. A potential level of regulation of glucose uptake is at the level of the glucose transporters [19]. This study demonstrates that pre-translational regulation of GLUT-3 mRNA may occur in cells incubated in high concentration of glucose. If the decrease in the level of GLUT-3 mRNA is reflected by a concomitant decrease in the level of GLUT-3 protein, then the cells will have effectively reduced their capacity to transport glucose in these conditions. However, GLUT-3 has a very low $\mathrm{k}_{\mathrm{m}}$ for glucose [19] and as such it ensures efficient uptake of glucose even at low extracellular glucose concentrations, but the limiting factor here will be the level of the GLUT-3 protein, not the glucose concentration. The protective ability of this regulatory mechanism may therefore be insufficient to protect the cell from glucose toxicity.

The ability of glucose transporter mRNA to be regulated in response to changes in the concentration of glucose has been reported previously [20]. These observations suggested that hyperglycaemia had a role in the down-regulation of the D-glucose transport system in rat brain glial cells. Glucose transporter protein and mRNA has also been shown to be increased in experimental diabetes [21], indicating the potential role that the glucose transporters may have in the maintenance of glucose homeostasis in diabetes. The changes that we observe in this study in the level of GLUT-3 mRNA are important for the demonstration of a functional glucose transport system in the retina.

The difference in the relative levels of GLUT-3 mRNA present in endothelial cells incubated in medium containing glucose compared to that obtained with cells incubated in medium supplemented with galactose, raises the question as to whether galactosaemia is a suitable model for diabetic retinopathy. Although the response to high concentrations of glucose and galactose is directionally similar, the magnitude of the response was considerably different. The kinetics of uptake and utilization of glucose or galactose by GLUT 3 is known to be fundamentally different [13]. Although galactosaemia has been found to induce some of the early complications of diabetic retinopathy [22] the effects on the lens predominate over the retinal changes [23]. In contrast, ocular complications in diabetes are more prevalent in the retina than in the lens. An additional factor is the known association of cataracts with genetic defects in the enzymic conversion of D-galactose to D-glucose [24]. In both types of galactosaemia the cataracts appear to be caused by the accumulation of galactitol, formed in the lens from $\mathrm{D}$-galactose by aldose reductase.

We monitored the level of aldose reductase mRNA expression in the respective cell types in order to further elucidate the mechanisms associated with an increase in the concentration of glucose. Aldose reductase facilitates the 
conversion of D-glucose to the sugar alcohol, sorbitol [25] and this enzyme has a low affinity for glucose. Thus, it only plays a significant role at supraphysiological concentrations of hexoses. Aldose reductase has been shown to be activated in the lens of hypergalactosaemic rats [11] and in patients with long-term diabetes [26]. A similar increase in the level of aldose reductase mRNA is observed in this study in both BREC and BRP. In the light of the increase in the level of aldose reductase mRNA in $25 \mathrm{mmol} / \mathrm{lglu}$ cose in which there has been a reduction in the level of GLUT-3 mRNA, we postulate that the decline in the level of GLUT-3 mRNA is insufficient to confer any real protection against high levels of glucose. However, this does not take into account the stability of the respective mRNAs which may also be changing in response to the imposed conditions.

The magnitude of the alterations in the level of GLUT3 and aldose reductase mRNA is greater in the pericytes than in the endothelial cells. This may reflect a greater sensitivity of the pericytes to high concentrations of glucose. However, this may simply be due to the different culture conditions and it is therefore not possible to make any direct comparisons between the two sets of results.

There are clearly many complex interactions which take place in the retina, with respect to glucose uptake and utilization and the potential for the development of toxic effects. Therefore, further understanding of glucose regulatory mechanisms in retinal cells would greatly enhance our potential to understand the association between diabetic retinopathy and glucose regulation with diabetes mellitus.

Acknowledgements. We would like to thank the following people for kindly donating the cDNAs that were used in this study: Dr. G. Gould (Department of Biochemistry, University of Glasgow) for the GLUT-3 cDNA, Professor S. Lightman (Institute of Ophthalmology, London) for the aldose reductase cDNA originally from Dr. Petrash (Department of Ophthalmology, Washington University School of Medicine, St. Louis, Mo., USA) Dr. J.Hesketh (The Rowett Research Institute, Aberdeen) for the $\alpha$-actin cDNA, originally obtained from Dr. G. Goldspink (Royal Veterinary College, London). We would also like to thank 'Fight for Sight' for their financial support of this work.

\section{References}

1. Herman WH, Teutsch SM, Sepe SJ, Sinnock P, Klein R (1983) An approach to the prevention of blindness in diabetes. Diabetes Care 6: 608-613

2. Klein R, Klein BEK, Moss SE, Davis MD, DeMeyts DL (1984) The Wisconsin epidemiologic study of diabetic retinopathy. II Prevalence and risk of diabetic retinopathy when age at diagnosis is less than 30 years. III Prevalence and risk of diabetic retinopathy when age at diagnosis is 30 years or more. Arch Ophthalmol 102: 520-532

3. Gould G, Bell GI (1990) Facilitative glucose transporters: an expanding family. Trend Biochem Sci 15:18-23

4. Gould GW, Brant AM, Kahn BB, Shepherd PR, McCoid SC, Gibbs EM (1992) Expression of the brain type glucose transporter is restricted to brain and neuronal cells in mice. Diabetologia 35: 304-309

5. Nagamatsu S, Kornhauser JM, Burant CF, Seino S, Mayo KE, Bell GI (1992) Glucose transporter expression in Brain. J Biol Chem 267: 467-472

6. Gerhart DZ, Broderius MA, Borson ND, Drewes LR (1992) Neurons and microvessels express the brain glucose transporter protein GLUT-3. Proc Natl Acad Sci USA 89: 733-737
7. Kinoshita JH, Fukushi S, Kador P, Merola LO (1979) Aldose reductase in diabetic complications of the eye. Metabolism 28: 462-469

8. Akagi Y, Kador PF, Kuwabara T, Kinoshita JH (1983) Aldose reductase localization in human retinal mural cells. Invest Ophthalmol Vis Sci 24: 1516-1519

9. Frank RN, Keirn RJ, Kennedy A, Frank KW (1983) Galactoseinduced retinal capillary basement membrane thickening: prevention by sorbinil. Invest Ophthalmol Vis Sci 24: 1519-1524

10. Lightman S, Rechthand E, Terubayashi H, Palestine A, Rapoport S, Kador P (1987) Permeability changes in blood-retinal barrier of galactosemic rats are prevented by aldose reductase inhibitors. Diabetes 36: 1271-1275

11. Lightman S, Bondy C, Lightman S, Kador P (1990) Aldose reductase messenger RNA in the lens epithelium in vivo: effects of diabetes mellitus and galactosemia. Clin Sci 79: 599-603

12. Chomczynski P, Sacchi N (1987) Single-step method of RNA isolation by acid guanidinium thiocyanate-phenol-chloroform extraction. Anal Biochem 162: 156-159

13. Gould GW, Thomas HM, Jess TJ, Bell GI (1991) Expression of human glucose transporters in Xenopus oocytes: kinetic characterization and substrate specificities of the erythrocyte, liver and brain isoforms. Biochemistry 30: 5139-51.45

14. Petrash N, Favello AD (1989) Isolation and characterization of cDNA clones encoding aldose reductase. Curr Eye Res 8: 10211027

15. Sognier MA, Neft RE, Roe AL, Eberle RL, Belli JA (1991) Dotblot hybridization: quantitative analysis with direct beta counting. Biotechniques 11: 520-525

16. Yano H, Seino Y, Inagaki $N$ et al. (1991) Tissue distribution and species difference of the brain type glucose transporter (GLUT3). Biochem Biophys Res Comm 174: 470-477

17. Bondy CA, Lightman SL (1989) Development and physiological regulation of aldose reductase mRNA expression in renal medulla. Mol Endocrinol 3: 1409-1416

18. Li W, Chan LW, Khatami M, Rockey JH (1985) Characterization of glucose transport by bovine retinal capillary pericytes in culture. Exp Eye Res 41: 191-199

19. Inagaki N, Yasuda K. Inoue G et al. (1992) Glucose as a regulator of glucose transport activity and glucose transporter mRNA in hamster $\beta$-cell line. Diabetes 41: 592-597

20. Walker PS, Donovan JA, Van Ness BG et al. (1988) Glucose dependent regulation of glucose transport activity, protein and mRNA in primary cultures of rat brain glial cells. J Biol Chem 263: $15594-15600$

21. Choi TB, Boado RJ, Pardridge WM (1989) Blood-brain barrier glucose transporter mRNA is increased in experimental diabetes. Biochem Biophys Res Comm 164: 375-380

22. Engerman RL, Kern TS (1984) Experimental galactosemia produces diabetic-like retinopathy. Diabetes 33:97-100

23. Sato S, Takahashi Y, Wyman M, Kador PF (1991) Progression of sugar cataract in the dog. Invest Ophthalmol Vis Sci 32: 19251931

24. Vaca-Pacheco G, Medina C, Garcia-Cruz D et al. (1990) Identification of inborn metabolic errors of galactose in patients with cataracts. Arch Invest Med 21: 127-132

25. Gabbay KH (1973) The sorbitol pathway and the complications of diabetes. N Eng1 J Med 288: 831-836

26. Vinores SA, Campochiaro PA, Williams EH, May EE, Green WR (1988) Aldose reductase expression in human diabetic retina and retinal pigment epithelium. Diabetes 37: 1658-1664

Received: 16 February 1993

and in revised form: 4 May 1993

Dr. R. M. Knott

Department of Ophthalmology

University Medical Buildings

Foresterhill

Aberdeen AB9 2ZD

UK 